\title{
Building a solid foundation - sulphur, phosphorus and potassium requirements for the sedimentary soils of North Canterbury
}

\author{
A.H.C. ROBERTS', T.H. WEBB ${ }^{2}$, J.D. MORTON ${ }^{3}$, M.B. O'CONNOR' and DC. EDMEADES ${ }^{1}$ \\ ${ }^{1}$ AgResearch Ruakura, Private Bag 3123, Hamilton \\ ${ }^{2}$ Manaaki Whenua - Landcare Research, PO Box 69, Lincoln \\ ${ }^{3}$ AgResearch Invermay, Private Bag 50034, Mosgiel
}

\begin{abstract}
The soils of North Canterbury occur mainly on steep land (31\%), hilly land (28\%), rolling downs and downlands (11\%) and terraces and floodplains $(30 \%)$. Most soils are predominantly formed from greywacke and tertiary sediments and some $85 \%$ comprise yellow-grey earth, yellow-grey earth to yellow-brown earth intergrade, yellow-brown earth and recent soil groups. In terms of the relationship between pasture production and fertiliser nutrient use these major soil groups are considered as a single entity, namely "sedimentary" soils (a reference to their derivation from sedimentary rocks). The relationships (production functions) between pasture production and soil test level for sulphur $(\mathrm{S})$, phosphorus $(\mathrm{P})$ and potassium $(\mathrm{K})$ are shown to be of the "diminishing returns" type for the sedimentary soils and the point at which near-maximum production $(97 \%)$ occurs is defined as the "biological optimum" soil test level. Biological optimum sulphate-S and organic-S -levels_are 10 and 15 respectively, for Olsen $P$ is 20 and quick-test $\mathrm{K}$ is 6 . Once the biological optimum soil test levels have been attained then maintenance fertiliser nutrient rates are appropriate. In order to correct $S$ deficiency sedimentary soils require an average of $35 \mathrm{~kg} \mathbf{S} / \mathrm{ha}$. To move up the pasture production curve an average of $\mathbf{5}$ $\mathrm{kg} \mathrm{P} /$ ha above maintenance will increase Olsen $\mathrm{P}$ by 1 unit. Potassium requirements depend on soil group within the sedimentary soils.
\end{abstract}

Keywords: biological-optimum, North Canterbury, nutrient requirements, phosphorus, potassium, sedimentary soils, sulphur

\section{In t r o d u c t i o n}

Soils are formed by a number of factors, including parent material, climate, time, topography, soil-living organisms (Jenny 1941) and the modifying influence of human activity. Soil processes (e.g. leaching, podzolisation, gleying, humification and biological disturbance) acting in conjunction with the soil-forming factors result in the soil mantle which is one of the fundamental resources available to farmers. The first section of this paper describes the distribution of these resources in North Canterbury, their physical characteristics and land use.

While the soils are the growing media for pasture, in their natural state they may be deficient in one or more of the essential elements required for maximum grass/legume productivity. If a farmer's objective is to produce as much pasture as possible then these nutrient deficiencies will need to be corrected. The assessment of soil fertility, on farm, is currently most often made using a combination of soil testing and past fertiliser history and then deciding on nutrient requirements accordingly. One formal method of determining nutrient requirements is the CFAS approach (Cornforth \& Sinclair 1984) although this is essentially a maintenance model, i.e., the nutrient requirement is calculated to replace the annual losses of $\mathrm{S}, \mathrm{P}$ and $\mathbf{K}$ and does not fully cover the spectrum from farm development through to true maintenance situations.

Recently, over 3000 data-sets derived from archival and recent soil fertility trials conducted by MAF/ Ag Research ${ }^{-}$science $^{-}$staff-have-been-collated-into-an electronic database and analysis of this information has enabled the relationships (production functions) between relative pasture production and the soil tests for $\mathrm{S}, \mathrm{P}$ and $\mathrm{K}$ to be defined for sedimentary soils. Previously, only limited data relating soil test (primarily Olsen P) and pasture production have been published (Grigg 1977; Saunders et al. 1987). The relationships and practical information to help formulate fertiliser policies arising from the database information are presented and discussed in the second section of this paper.

\section{Soils of North Canterbury}

In this paper, North Canterbury is defined as the land area bounded by the Clarence river in the north, the Waimakariri river to the south, the coast to the east and the Southern Alps to the west. A summary of soil classification and soil areas for North Canterbury are presented in Table 1. The soils in this area occur on four major landforms: 
Table 1 Soil groups of North Canterbury.

\begin{tabular}{|c|c|c|c|}
\hline Soil Group & Physiographic unit & Area' (1000 ha) & Area $(\%)$ \\
\hline \multirow[t]{3}{*}{ Yellow-grey earth } & Rolling land with deep loess & 44 & 6.5 \\
\hline & Hilly land from Tertiary sediments & a 5 & 12.5 \\
\hline & Steep land from greywacke & 74 & 11 \\
\hline Yellow-brown stony soils & Terraces from greywacke & 48 & 7 \\
\hline \multirow[t]{3}{*}{ Yellow-grey to yellow-brown intergrades } & Rolling land with deep loess & 28 & 4 \\
\hline & Hilly land from Tertiary sediments & 75 & 11 \\
\hline & Terraces from greywacke & 45 & 7 \\
\hline \multirow[t]{2}{*}{ Yellow-brown earth } & Terraces and fans from greywacke & 6 & 1 \\
\hline & Steep land from greywacke & 137 & 20 \\
\hline Yellow-brown sands & Coastal dunes & 7 & 1 \\
\hline Rendzinas & Mainly hilly land from Tertiary sediments & 24 & 3.5 \\
\hline Brown granular clays & Mainly hilly land from Tertiary sediments & 8 & 1 \\
\hline Gley soils & Terraces and flood plains from greywacke & 20 & 3 \\
\hline Recent soils & Terraces and flood plains from greywacke & 79 & 12 \\
\hline
\end{tabular}

" From Long (1966)

\section{(a) Steep land (31 percent of total area)}

Extensive areas of steep land occur in two main belts:

(i) A long belt of steep land occurs as a transition to the high country, 30 to $50 \mathrm{~km}$ from the coast. This land mainly contains yellow-brown earths (Hurunui soils) but large areas of yellow-grey earths (Haldon soils) occur on the drier eastern side, particularly in the north.

(ii) Large areas of dry steepland yellow-grey earths (Haldon soils) occur within $30 \mathrm{~km}$ of the coast with the Lowry Peak Range making up the bulk of the area. North of the Waiau River the climate is humid and the soils are classified as yellow-brown earths.

The Hurunui soils occur under a humid climate. They are friable soils predominantly of stony silt loam texture and of variable depth and are well suited to pastoral and forestry uses.

The Haldon soils occur under a $600-850 \mathrm{~mm}$ rainfall and suffer severe droughtiness. Yellow-grey earth features are only weakly expressed due to rejuvenation on steep slopes and to high stone contents in subsoil horizons. Soils are predominantly shallow gravelly silt loams with angular fragments of greywacke. Numerous outcrops of greywacke occur. These soils are almost exclusively used for extensive grazing as severe droughtiness limits production potential.

\section{(b) Hilly land (28 percent of total area)}

Hilly land is mainly confined to within $30 \mathrm{~km}$ of the coast and consists mainly of yellow-grey earths (formed from deep loess or fine colluvium) and yellow-grey to yellow-brown earth intergrades (formed on old gravel beds). Smaller areas contain rendzinas (from limestone) and brown granular clays (from volcanic rock). Hilly land is mainly confined to within $30 \mathrm{~km}$ of the coast.

Soils are highly variable in depth and texture due to different textures of parent materials and varying amounts of loess in soil profiles. Consequently, a large number of soils are distinguished. In the subhumid area soils are mapped as Amberley, Glenmark, Taiko and Tipapa sets, in the intermediate rainfall area as Glendhu, Gower, Leader, Makerikeri, Stonyhurst sets and in wetter areas as Kahutara, Hundalee and Onepunga sets.

Rendzinas, formed from limestone, and brown granular clays, formed from basaltic tuffs occupy relatively small areas in the Waikari Basin, near Waiau, and near the coast between the Hurunui and Waipara rivers. These soils generally have dark, organic-rich topsoils and friable, strongly structured subsoils.

\section{(c) Rolling downs and downland margins (11 percent of total area)}

Soils on rolling downs and downland margins are formed from loess, or loess and colluvium, from greywacke 
and other siliceous material such as sandstone. In general the soils are yellow-grey earth or yellow-grey earth yellow-brown earth integrades and have dark silt loam topsoils over olive-brown subsoils with an underlying fragipan (a dense horizon which limits root growth and has slow permeability). These soils form a sequence of soils with increasing rainfall of Waipara, Ashley, Cheviot and Oxford sets. Soils become increasingly acid with rainfall and more poorly drained with increasing rainfall or with decreasing slope angle. These lands are mostly suited to pastoral use and have limitations of droughty summers and waterlogging in winter/early spring. Soils on the downlands margin (Mairaki, Domett, Wakanui) are also used for cropping.

\section{(d) Terraces and flood plains (30percent of total area)}

Terraces and flood plains are composed of:

(i) Shallow and stony soils on older surfaces in the Amuri and Waikari Basins and on the extensive outwash surface to the north of the Waimakariri River.

These soils (mainly represented by Lismore, Balmoral and Chertsey soils) are mainly used for grazing, although a significant area at Balmoral and Eyrewell are used for Pinus Radiata plantations. Shallow and stony soils are prone to severe droughtiness. They are used for intensive grazing under border dyke irrigation in the Amuri Plains.

(ii) Deep to very stony soils on younger surfaces in association with the-Eyre,-Ashley,-Kowai-Waitohi, Hurunui and Waiau Rivers.

These soils have variable potential largely dependent upon their depth of fine textured material and availability of irrigation. Templeton soils and the deeper phases of the Waimakariri soils are used for cropping and horticulture.

(iii)A relatively small but significant area of poorly drained gley soils in the south around Rangiora and Kaiapoi.

These soils are used for grazing and have traditionally been used for dairying.

Sulphur, phosphorus and potassium requirements for North Canterbury soils

Collectively, the soil groups yellow-grey earth, yellowbrown earth, yellow-grey to yellow-brown earth intergrades and recent soils occupy $85 \%$ of North Canterbury. For the purposes of establishing the relationship between relative pasture production and soil test (production function), relevant trials conducted on these four soil groups throughout the lower half of the North Island and the whole South Island have been grouped together.

This approach is valid for the following reasons: (a) the soils are all derived from similar parent materials and therefore their chemistry with respect to $\mathrm{S}, \mathrm{P}$ and $\mathrm{K}$ will be similar. Thus, the production functions are expected to be similar; (b) data from individual trials are often variable. Combining data from a number of sites (in effect treating trials as replicates) or similar soils reduces the variability (see Sinclair et al. 1994) and enables meaningful average relationshps to be developed; (c) these relationships have a useful practical meaning and application at the farm level, given the precision required in making fertiliser recommendations.

The production functions have been developed using spline functions (Upsdell 1985) and the 95\% confidence intervals for the average relationship are also shown. In general, the production functions are curvilinear in nature. The "biological optimum" soil test level has been defined as that at which $97 \%$ of relative pasture production is achieved. The 97\% has been arbitrarily chosen because that level is close to near-maximum pasture production and, by definition, diminishing returns curves of the Mitscherlich type will reach $100 \%$ only at infinity.

\section{Sulphur}

There are two soil tests used for determining the $\mathrm{S}$ status-of-soils,-namely-the sulphate=S_test_(Saunders_et al. 1981) used to measure immediately available $S$ and the extractable organic-S test (Watkinson et al. 1991) which measures more slowly available $\mathrm{S}$. The biological optimum sulphate-S test is 10 (Fig. 1) while for organic$\mathrm{S}$ it is 15 (Fig. 2). However, quoting single soil test values attributes too much precision to soil testing and so a target range is given which indicates a high probability of sustaining near maximum pasture production. The target range for sulphate-S is 10-12 and for organic-S is 15-20 for sedimentary soils.

$\mathrm{T} h$ e sulphate-S and-organic-S tests-should-be-use together. Low levels for both tests indicate a need for capital application of S fertiliser while high levels indicate maintenance $\mathrm{S}$ is required.

Field trial results show that $S$ deficiencies may be overcome with moderate inputs, provided the form of S (either sulphate or elemental-s) appropriate to the individual farm situation is applied. For sedimentary soils, the average amount of $\mathrm{S}$ required to completely overcome a deficiency is $35 \mathrm{~kg} / \mathrm{ha}$ (range 30-40). 
Figure 1 The relationship between relative pasture production and soil sulphate for sedimentary soils.

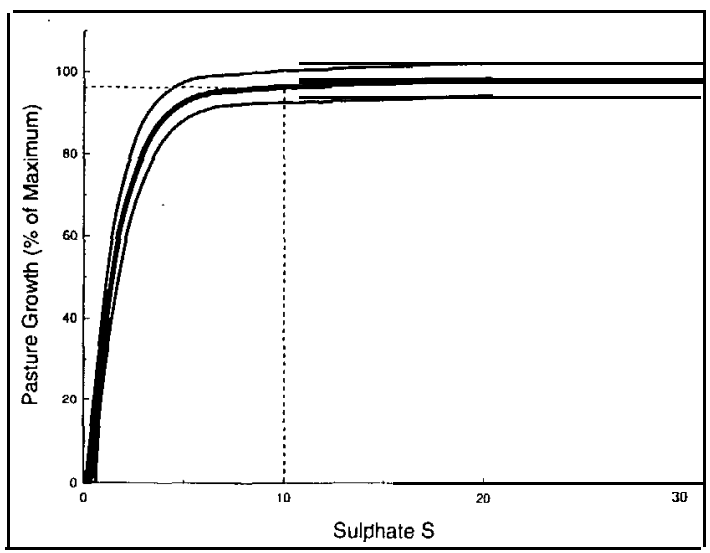

Figure 3 The relationship between relative pasture production and Olsen $P$ test for sedimentary soils.

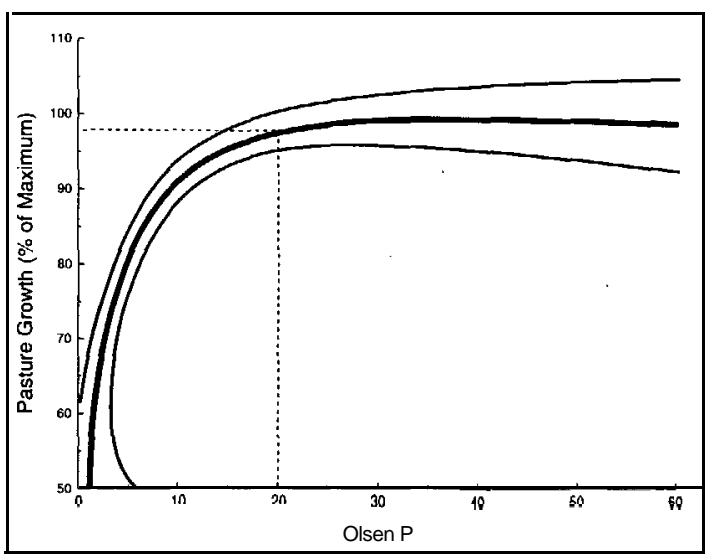

\section{Phosphate}

The predominant soil test used for assessing the $\mathrm{P}$ status of soils in New Zealand is the Olsen test (Olsen et al. 1954). The biological optimum Olsen $P$ test for sedimentary soils is 20 (Fig. 3) and the target range for Olsen $\mathrm{P}$ which will sustain near maximum pasture production is $20-25$.

If the Olsen $\mathrm{P}$ status of sedimentary soils is low, large capital inputs of $\mathrm{P}$ fertiliser are required for a rapid increase to occur. It is much more effective to apply a high rate of $\mathrm{P}$ over 1 or 2 years than to apply the same amount of $\mathrm{P}$ over several years. Field trials have indicated that on average $5 \mathrm{~kg} \mathrm{P} / \mathrm{ha}$ (range 4-7), over and above those required to replace the annual losses from the farm, will be required to raise Olsen $\mathrm{P}$
Figure 2 The relationship between relative pasture production and organic $S$ for sedimentary soils.

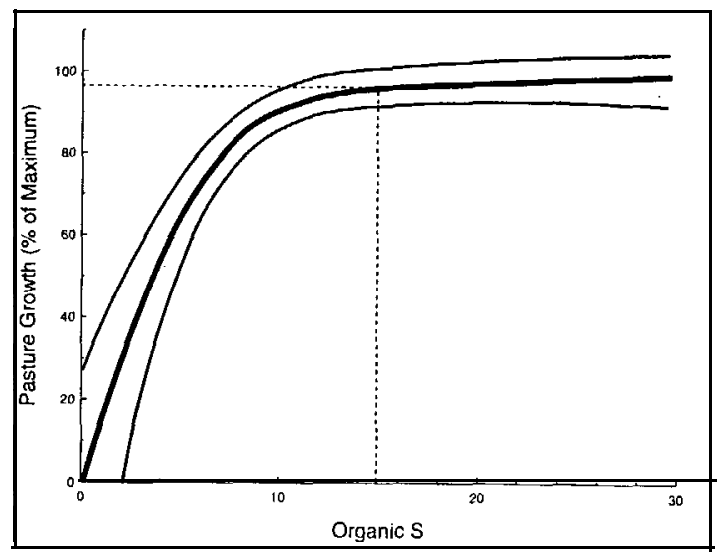

Figure 4 The relationship between relative pasture production and soil test $\mathrm{K}$ for sedimentary soils.

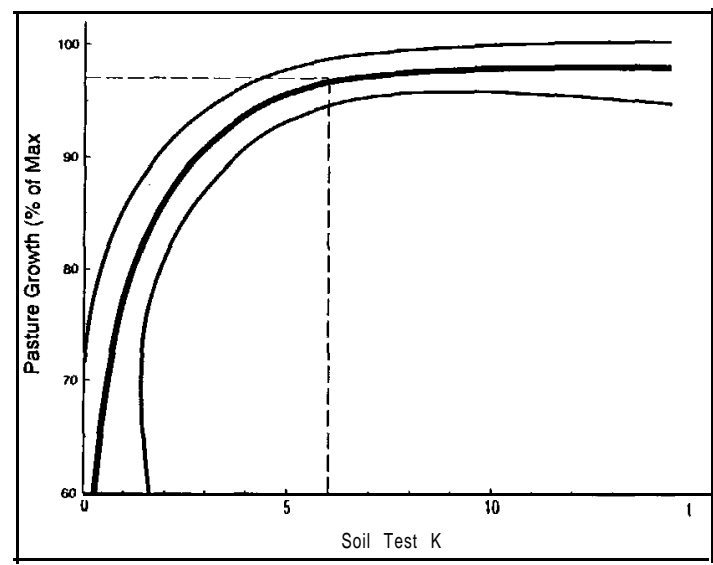

by 1 unit. Thus, to raise the Olsen $P$ status of a sedimentary soil from 15 to 25 , i.e., 10 Olsen $\mathrm{P}$ units, some $50 \mathrm{~kg} \mathrm{P} / \mathrm{ha}$ of capital fertiliser will be required.

\section{Potassium}

Two soil tests are used to assess the potassium fertility of soils. These are the quick test $\mathrm{K}$ (Cornforth 1980) and the tetraphenylboron - extractable $\mathrm{K}$ (TBK) soil test (Jackson 1985). The relationship between pasture production and quick test $\mathrm{K}$ shows that the biological optimum is 6 (Fig. 4) and the target range to sustain near maximum pasture production is 5-8.

Some sedimentary soils, particularly recent alluvial and yellow-grey earth soils of the South Island provide considerable amounts of $\mathrm{K}$ for plant growth. This $\mathrm{K}$ is 
provided by continual weathering of soil clay minerals and plant-available (but non-exchangeable) $\mathrm{K}$ held in the soil but which is not measured by the standard quick test procedure. An assessment of this "reserve" $\mathrm{K}$ is given by the TBK test. Currently, there is little interpretive data available for use with the TBK test. However, data from a limited range of field experiments (e.g. Risk, W.H. unpubl.; Smith, R.G. unpubl.) suggest that near maximum pasture production was obtained over a value of about $0.8 \mathrm{me} \%$.

Within the sedimentary soil group, yellow grey earth and recent soils are unlikely to require capital applications of $\mathrm{K}$ and may not even require maintenance $\mathrm{K}$ applications where reserve $\mathrm{K}$ levels are high. Yellowbrown earths may require $K$ and the reserve $K$ levels should be estimated using the TBK test.

\section{Maintaining soil fertility}

Once the biological optimum soil test or target range is reached, maintenance rates of fertiliser nutrients apply. At maintenance, nutrient requirements are simply the amounts needed to replace the losses of nutrients from livestock or their products leaving the farm, dung and urine deposited in gateways and stock camps and the inevitable losses of nutrients which occur in soils. Thus, nutrient losses at maintenance vary predominantly as a

Table 2 Maintenance nutrient requirements $(\mathrm{kg} / \mathrm{ha})$ in relation to stocking rate for sheep/beef fanning.

\begin{tabular}{cccc}
\hline $\begin{array}{c}\text { Stocking-rate- } \\
\text { (SU/ha) }\end{array}$ & S & Maintenance-rate & \\
\hline 7 & $6-13$ & $6-12$ & $\mathbf{K}^{*}$ \\
10 & $8-19$ & $10-16$ & $17-21$ \\
13 & $10-23$ & $15-22$ & $22-28$ \\
16 & $13-27$ & $21-28$ & $32-41$ \\
19 & $15-31$ & $28-35$ & $37-48$ \\
22 & $17-35$ & $34-44$ & $42-54$ \\
\hline
\end{tabular}

Maintenance $\mathrm{K}$ for grazed pasture is only required on soils with low $\mathrm{K}$ reserves.

Table 3 Maintenance nutrient requirements $(\mathrm{kg} / \mathrm{ha})$ in relation to stocking rate for dairying.

\begin{tabular}{cccc}
\hline $\begin{array}{c}\text { Stocking rate } \\
\text { (cows/ha)' }\end{array}$ & P & $\begin{array}{c}\text { Maintenance rate } \\
\text { K" }\end{array}$ & S \\
\hline 2 & $20-23$ & $20-30$ & $20-30$ \\
2.5 & $27-30$ & $30-40$ & $23-27$ \\
3 & $34-37$ & $40-50$ & $27-32$ \\
3.5 & $43-46$ & $50-60$ & $32-37$ \\
4 & $54-57$ & $60-70$ & $37-42$ \\
\hline ! cow at 350 kg liveweight producing 290 kg milksolids \\
" K requirements with soils of low TBK reserves (TBK<1.0) \\
Requirements will be less at higher TBK levels \\
\hline
\end{tabular}

function of stocking rate and soil properties. Typical maintenance nutrient requirements for the sedimentary soils, such as those of North Canterbury, are shown in Tables 2 and 3 .

\section{Economic versus biological optimum soil test levels}

The biological optimum soil test and target range values assume that a farmer's objective is to grow near maximum pasture production. The economically optimum soil test levels will depend on the individual farm situation in terms of both physical and financial factors. Generally, as gross farm income increases so the economic optimum soil test level will approach closer to the biological optimum. For example, at current costs and prices intensive dairy farmers on the terraces and floodplains around Rangiora and Kaiapoi could justifiably have an objective to raise soil fertility status to the target range for near maximum pasture production (thereby embracing the biological optimum) In contrast, extensive sheep and beef farmers in the foothills of the Southern Alps may find that appropriate soil test levels for their farm situation are well short of the biological optimum.

\section{Summary}

One of the lynch-pins of grassland production is the soil resource. In order to achieve the production goals and economic outcomes desired, farmers need to utilise and enhance the chemical, physical and biological attributes-of-the-soils-on-their-properties.-In_order_to meet the nutrient requirements of the major livestock feedstuff, perennial grass/legume pastures, farmers or their advisors need to identify the soils they are dealing with and the principles governing the relationship between pasture growth and soil fertility status. This paper has endeavoured to provide this information.

\section{REFERENCES}

Cornforth, IS. 1980. Soil and fertilisers: Soil analysis interpretation. AgLink AS-T -8. -Wellington; -New Zealand Ministry of Agriculture and Fisheries.

Comforth, I.S.; Sinclair, A.G. 1984. Fertiliser and lime recommendations for pastures and crops in New Zealand. (Second revised edition). Wellington, New Zealand Ministry of Agriculture and Fisheries. 66p. Grigg, J.L. 1977. Prediction of plant response to fertiliser by means of soil tests V. Soil tests for phosphorus availability in brown-grey and dry-subhygrous yellow-grey earths. New Zealand journal of agricultural research 20: 3 15-326. 
Jackson, B.L.J. 1985. A modified sodium tetraphenyl boron method for the routine determination of reserve potassium status of soil. New Z ealand journal of experimental agriculture 13: 253-262.

Jenny, H. 1941. Factors of soil formation. McGrawHill, New York.

Long, P.A. 1966. Areas of Soils of South Island, New Zealand. NZ Soil Bureau Report 3. 89 p.

Olsen, S.R.; Cole, C.V.; Watanabe, F.S.; Dean, L.A. 1954. Estimation of available phosphorus in soils by extraction with sodium bicarbonate. United States Department of Agriculture Circular No. 939:1-9.

Saunders, W.M.H.; Cooper, D.M.; Sinclair, A.G. 1981. Soils and Fertilisers:Sulphur. AgLink FPP 649. Wellington, New Zealand Ministry of Agriculture and Fisheries.

Saunders, W.M.H.; Sherrell, C.G.; Gravett, I.M. 1987. A new approach to the interpretation of soil tests for phosphate response by grazed pastures. New
Zealand journal of agricultural research 30: 67 78.

Sinclair, A.G.; Johnstone, P.D.; Smith,L.C.;Risk, W.H.; Morton, J.D.; O'Connor, M.B.; Roberts, A.H.C.; Nguyen, L.; Shannon, P.W. 1994. Patterns of, and a model for, dry matter response in grass/clover pastures to annual applications of triple superphosphate fertilisers. New Zealand journal of agricultural research 37: 239-253.

Upsdell, M.P. 1985. Bayesian inference for functions. Ph.D. thesis, University of Nottingham. 210p.

Watkinson, J.H.; Perrott, K.W.; Thorrold, B.S. 1991. Relationship between the MAF pasture development index of soil and extractable organic sulphur. In Soil and Plant Testing for Nutrient Deficiencies and Toxicities. (Eds. R.E.White and L.D.Currie) Occasional Report No.5. Fertiliser and Lime Research Centre, Massey University, Palmerston North, pp 66-71. 